University of Nebraska - Lincoln

DigitalCommons@University of Nebraska - Lincoln

May 1992

\title{
Simulating Winter Wheat Production in Three Tillage Systems Using the Nitrogen Tillage Residue Management Model
}

\author{
B. Davidoff \\ Office of Water Conservation, Sacramento, CA \\ Wallace Wilhelm \\ University of Nebraska-Lincoln, wwilhelm1@unl.edu \\ Joseph M. Skopp \\ University of Nebraska-Lincoln, jskopp1@unl.edu
}

Follow this and additional works at: https://digitalcommons.unl.edu/usdaarsfacpub

Part of the Agricultural Science Commons

Davidoff, B.; Wilhelm, Wallace; and Skopp, Joseph M., "Simulating Winter Wheat Production in Three Tillage Systems Using the Nitrogen Tillage Residue Management Model" (1992). Publications from USDAARS / UNL Faculty. 94.

https://digitalcommons.unl.edu/usdaarsfacpub/94

This Article is brought to you for free and open access by the U.S. Department of Agriculture: Agricultural Research Service, Lincoln, Nebraska at DigitalCommons@University of Nebraska - Lincoln. It has been accepted for inclusion in Publications from USDA-ARS / UNL Faculty by an authorized administrator of DigitalCommons@University of Nebraska - Lincoln. 


\title{
AGROCLIMATOLOGY
}

\section{Simulating Winter Wheat Production in Three Tillage Systems Using the Nitrogen Tillage Residue Management Model}

\author{
B. Davidoff, W. W. Wilhelm, ${ }^{*}$ and J. Skopp
}

\begin{abstract}
Crop production system analysis is necessary to identify tillage and residue management practices that affect crop production. The objective of this study was to evaluate the potential of using the Nitrogen Tillage Residue Management (NTRM) model to evaluate the influence of tillage practices on winter wheat (Triticum aestivum L.) yield. Modiffications of the NTRM model were required to simulate winter wheat production. The model was calibrated using site-specific information obtained from a tillage-nitrogen rate experiment conducted at the High Plains Agricultural Laboratory near Sidney, NE, on an Alliance silt loam (fine silty, mixed, mesic Aridic Argiustoll). Model output was compared to measured yields of winter wheat grown on three tillage treatments [moldboard plow, subsurface tillage (1.5 m-wide "V" blade), and no tillagel during three seasons. Simulations within the year of calibration agreed within $\pm 28 \%$ of measured yields for the moldboard plow and subsurface tillage treatments. Deviations were observed between predicted and measured yields when using data outside the year of calibration. Crop coefficients, determined in the calibration process, affected the yield predictions of NTRM. Grain yield predictions by NTRM were very sensitive to initial and stabilized soil bulk density values within the range of 1.2 to $1.3 \mathrm{Mg} \mathrm{m}^{-3}$ (1\% change in input value caused a five-fold change in predicted yield). Usefulness of the model could be enhanced through greater documen-
\end{abstract}

B. Davidoff, Dep. of Water Resources, Office of Water Conservation, Sacramento, CA 94236-0001; W.W. Wilhelm, USDAARS, Dep. of Agronomy, and J. Skopp, Dep. of Agronomy, Univ. of Nebraska, Lincoln, NE 68583-0915. Joint contribution of the ARS and Univ. of Nebraska, Agricultural Research Division. Journal Series no. 8991. Received 4 May 1990. *Corresponding author.

Published in Agron. J. 84:516-523 (1992). tation on calibration procedures and explanation of calibration coefficients. Results obtained here should alert users to the need for care in application of results obtained from complex, highly interlinked models, such as NTRM.

Crop production systems are influenced by a complex array of factors combining crop, soil, water, climate, and management parameters. Although many critical cropping system factors cannot readily be changed, soil and water conditions are greatly influenced by management and cultural practices that are controllable. Tillage is one management tool under direct human control that is used to modify the crop environment. Tillage practices have been devised through trial and error to provide better soil conditions for seed germination and crop development and growth. Because of the complex interactions among system components, systems analysis is a useful technique for defining cultural practices that optimize crop production strategies.

Simulation models are one tool for crop production system analysis. Simulation models can be used to analyze almost any conceivable condition within the production systems if the model(s) used in the exercise is (are) developed with realistic sensitivity to critical parameters and processes within the cropping system. Determining whether a particular model is appropri-

Abbreviations: NTRM, Nitrogen Tillage Residue Management; LAI, leaf area index; and SBD, stabilized bulk density. 
ately constructed is a critical part of the analytical procedure, and provided the motivations for this research.

During the past two decades, models have been developed to simulate crop development and growth. The Nitrogen Tillage Residue Management model is a comprehensive simulator that combines several submodels for simulating soil chemical and physical processes with those for development and growth responses of 20 crop species (Shaffer and Pierce, 1987; Shaffer and Larson, 1987). The model is large and segmented and provides a comprehensive mechanism for production system analysis through the variety of processes simulated. Swan et al. (1987) reported successful use of NTRM to simulate several management strategies for corn production. The objective of this research was to determine if the NTRM model could be applied to cropping system analysis of winter wheat grown under different tillage practices.

\section{MATERIALS AND METHODS}

\section{Field Site}

Simulation input data and field comparison data were obtained from a winter wheat-fallow tillage study (1978 through 1981) conducted at the High Plains Agricultural Laboratory near Sidney, NE. Information for the first crop of this study (September 1978 through July 1979) will be referenced as Season 1. Likewise, the crops grown from September 1979 through July 1980 and September 1980 through July 1981 will be referred as Season 2 and Season 3 , respectively. Soil at the site is an Alliance silt loam. Daily meteorological data were obtained from the National Oceanic and Atmospheric Administration (NOAA), National Climatic Data Center in Asheville, NC. Maximum and minimum air temperature and rainfall were collected about $0.8 \mathrm{~km}$ from the research site. Daily pan evaporation and wind speed were not measured on site. These data were obtained from the nearest available station, about $80 \mathrm{~km}$ from the research site.

The experimental site was divided into two sections; one planted and one fallow each year. Weed growth in stubble after wheat harvest (July) was chemically controlled, and fallow treatments (moldboard plow, subsurface tillage, and no tillage) were initiated in mid-April of the next year. 'Centurk' wheat was planted at $50 \mathrm{~kg} \mathrm{ha}^{-1}$ in mid-September at the end of the fallow period. Grain was harvested in mid-July of the following year and plots remained fallow for the next 14 mo. Tillage treatments were split into two subplots for $\mathrm{N}$ applications of 0 or $45 \mathrm{~kg} \mathrm{ha}^{-1}$. More detailed descriptions of the experimental site and cultural practices, preceding but similar to those used while these data were collected, were published by Fenster and Peterson (1979), Wilhelm et al. (1982), Broder et al. (1984), and Mielke et al. (1986).

The tillage treatments used in this study were moldboard plow, subsurface tillage ( $1.5 \mathrm{~m}$ - wide " $\mathrm{V}$ " blade), and no tillage. Treatment names define the primary tillage used in each treatment. Primary tillage tools in the moldboard plow and subsurface tillage treatments were operated at a depth of $100 \mathrm{~mm}$. (Although $100 \mathrm{~mm}$ is somewhat shallow for moldboard plow operation, it is the standard depth of primary tillage in this wheat production area.) $A$ number of secondary tillage operations were performed as required to control weeds in the moldboard plow and subsurface tillage treatments. Secondary tillage tools for these treatments were a field cultivator and a rotary rodweeder. Weeds in the no tillage treatment were controlled with herbicides.

Dry matter production was determined by harvesting all above-ground plant parts from a $0.91-\mathrm{m}^{2}$ area at selected times during crop development. Harvested samples were oven-dried at $85^{\circ} \mathrm{C}$ to a constant weight, then dry matter production was calculated. Leaf area index (LAI) was determined at heading from 50-culm subsamples. All green leaf blades ( $>50 \%$ green) were removed from each culm and passed through a leaf area meter (LI3000, LI-COR, Inc., Lincoln, NE) ${ }^{1}$. The LAI was calculated after determination of the leaf dry weight fraction and the specific leaf weight of the 50-culm subsample. Plant material was sampled from a $0.91-\mathrm{m}^{2}$ area to determine grain yield.

\section{Model Description}

The model used for this work was selected based on the criteria that it be (i) well documented; (ii) readily available; (iii) constructed to consider processes influenced by tillage; (iv) able to simulate development and growth of winter wheat; and (v) executable on available hardware (micro VAX II, Digital Equipment Company, Maynard, MA). The model NTRM (version 1.8, April 1986) was chosen because it was developed with the objective of simulating many soil physical, soil chemical, climatological, and managerial processes and because extensive documentation existed (Shaffer and Pierce, 1987; Shaffer and Larson, 1987). Detailed descriptions of submodels used to simulate soil, plant, and water movement processes have been reported by Shaffer and Pierce (1987), Shaffer and Larson (1987), and Swan et al. (1987).

A variety of input information is required by NTRM (Table 1). A simplified information flow chart and list of

Table 1. Summary of Nitrogen Tillage Residue Management inputs.

\begin{tabular}{ll}
\hline Type of data & \multicolumn{1}{c}{ Data } \\
\hline Climate & $\begin{array}{l}\text { Air temperature (maximum and minimum) } \\
\text { Precipitation } \\
\text { Pan evaporation } \\
\text { Solar radiation } \\
\text { Wind speed } \\
\text { Depth } \\
\text { Initial bulk density } \\
\text { Stabilized bulk density } \\
\text { Wail (by layer) } \\
\text { Initial water content and temperature }\end{array}$ \\
Management & $\begin{array}{l}\text { Particle size distribution } \\
\text { Wydraulic conductivity }\end{array}$ \\
Water characteristic curve \\
Tillage-type, date, and depth \\
Residue-type, cover, amount, and date \\
Fertilizer-type, amount, and date \\
$\begin{array}{l}\text { Planting, emergence, and harvest date } \\
\text { Plant population }\end{array}$ \\
$\begin{array}{l}\text { Dates of beginning and end of dormancy } \\
\text { Crop coefficients } \\
\text { Degree days to flowering and maturity }\end{array}$ \\
\hline
\end{tabular}

input files are shown in Fig. 1. Each component contains and uses a different category of input data. A brief description of steps taken to create and prepare various input files follows:

File A: Common input file, containing soil, crop and management practice data;

File B: Daily pan evaporation and wind speed data;

File C: Precipitation data;

File D: General soil temperature input data;

File E: Daily maximum and minimum air temperature data; data;

File F: Hourly measured or simulated air temperature

\footnotetext{
${ }^{1}$ Mention of trademark or registered product name does not imply a guarantee or suggest that the product is superior to others that may have a similar function by the Agricultural Research Service or the University of Nebraska.
} 

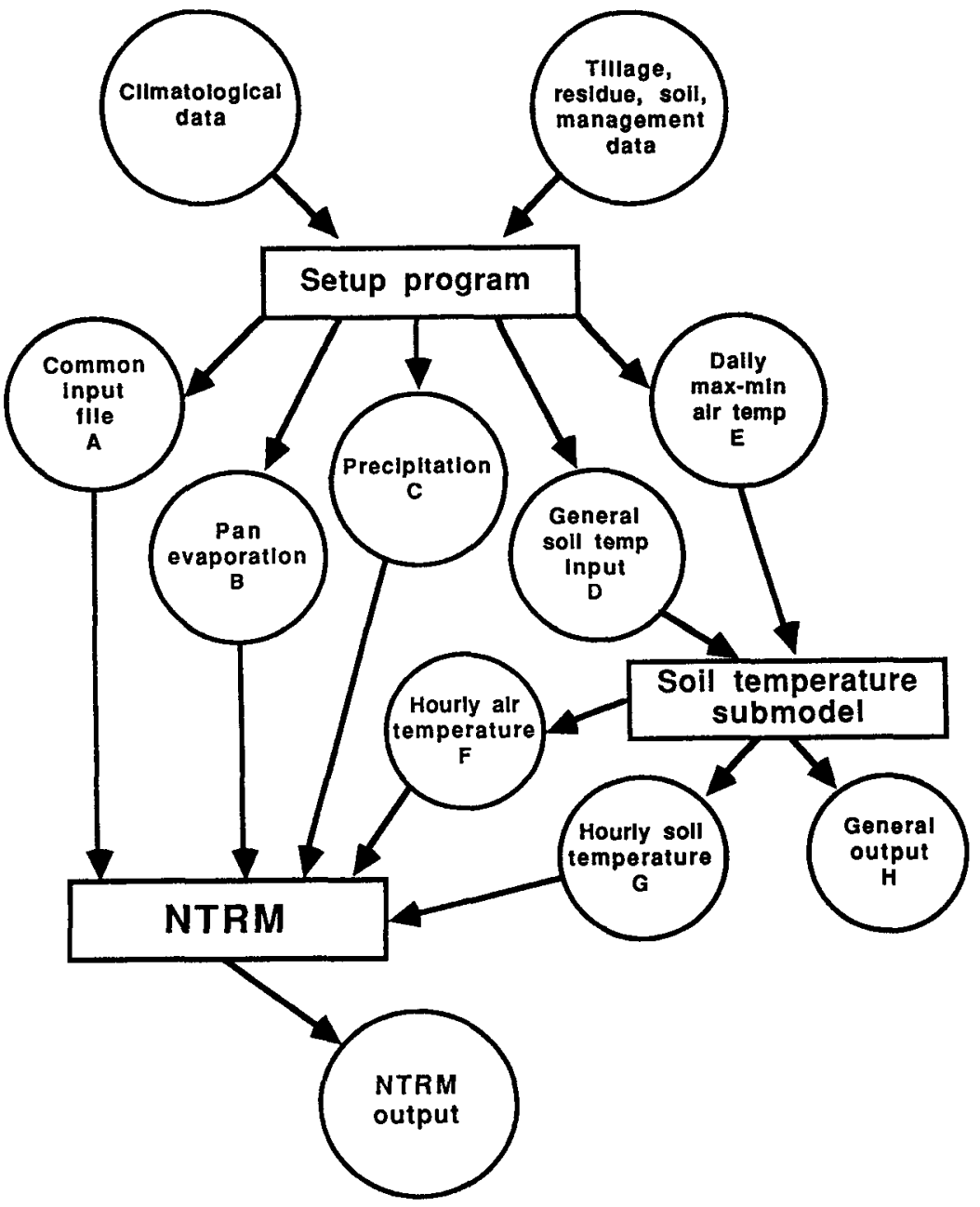

Fig. 1. A simplified input and output configuration of Nitrogen-Tillage-Residue Management (NTRM) model indicating the preparatory steps needed to run the model. Letters correspond to filenames in text.

File G: Hourly measured or simulated soil temperature data; and

File H: General output file.

The program SETUP was first used to create Files A, B, $C, D$, and $E$. Data for Files $B$ and $C$ were entered from daily meteorological records. Data for Files $A$ and $D$ were entered manually to provide soil, crop, tillage, and management information. The STSUB program was then executed using information in Files $D$ and $E$ to create Files $F$ and $G$, hourly air and soil temperature, respectively, and a general output file, File $\mathrm{H}$. Files A, B, C, F, and $\mathrm{G}$ were then used directly during the execution of the NTRM model.

\section{Model Modifications}

A modification of the model was necessary to allow simulation from one calendar year to the next. This was required for winter wheat (as well as any winter annual crop), which is planted in fall and harvested the following summer. Within NTRM a submodel, YSET, initializes all variables and simulated results. The YSET submodel was changed so initialization occurred $1 \mathrm{~d}$ after harvest and not at the end of the calendar year. Thus, simulated results were carried from planting to harvest.

A general rate modification equation of the form, $y_{1}=$ $y_{0}\left(\log _{10} t\right) / 4.0$, is used in four $\mathrm{N}$ balance subroutines (MI, RANI, TRNSFM, and UREAS) when $t \leq 10^{\circ} \mathrm{C}$. In this equation $y_{1}$ is the modified rate of the process in question, $y_{0}$ is the unmodified process rate, and $t$ is the hourly soil temperature. A second modification was introduced to avoid negative process rates when $0^{\circ}<t<1^{\circ} \mathrm{C}$ and uncontrolled failure of the model when non-positive soil temperature data were encountered. The modified process rate $\left(y_{1}\right)$ was set to zero when $t \leq 1^{\circ} \mathrm{C}$.

The model also predicted unrealistically rapid development and growth during winter. When this problem was recognized and discussed with the model's author, a third modification was introduced. A parameter was added to permit users to define dormancy, a period of arbitrary duration when no development and growth was allowed.

\section{Tillage Operation Selection}

Tillage operations simulated within the model were limited and were not completely comparable to operations used in the field study. The NTRM model allows the user to select among four tillage operations: moldboard plow, chisel plow, tandem disk, and no tillage. These operations are used to adjust a variety of internal model coefficients. For this work, chisel plow was selected to simulate subsurface tillage.

\section{Model Calibration}

The model was calibrated to the site conditions using the Season 2 data because the most complete and frequent observation of parameters needed for setting coefficients occurred during that season. Soil, plant, weather, and management data for the moldboard plow-no nitrogen treatment were selected as the calibration data set. While model 
Table 2. Measured (mean of four replications) and simulated grain yield of winter wheat grown with and without addition of $\mathrm{N}$ fertilizer under three fallow tillage practices

\begin{tabular}{|c|c|c|c|c|c|}
\hline \multirow{2}{*}{$\begin{array}{l}\text { Cropping- } \\
\text { season }\end{array}$} & \multirow[b]{2}{*}{ Tillage } & \multirow[b]{2}{*}{ Nitrogen } & \multicolumn{2}{|c|}{ Grain yield } & \multirow[b]{2}{*}{ Deviation $\ddagger$} \\
\hline & & & Measured $\dagger$ & Simulated & \\
\hline \multirow{5}{*}{ 1978-1979 } & & 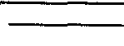 & $-\mathbf{k g h a}^{-1}$ & & $\%$ \\
\hline & Moldboard plow & 0 & $3039 \pm 281$ & 4941 & 63 \\
\hline & Subsurface tillage & $\begin{array}{r}45 \\
0\end{array}$ & $\begin{array}{l}3035 \pm 179 \\
2901 \pm 416\end{array}$ & $\begin{array}{l}4886 \\
4823\end{array}$ & $\begin{array}{l}61 \\
66\end{array}$ \\
\hline & & 45 & $3009 \pm 268$ & 5043 & 68 \\
\hline & No tillage & $\begin{array}{r}0 \\
45\end{array}$ & $\begin{array}{l}2917 \pm 352 \\
3050 \pm 246\end{array}$ & $\begin{array}{l}5818 \\
5689\end{array}$ & $\begin{array}{l}99 \\
87\end{array}$ \\
\hline \multirow{4}{*}{$1979-1980$} & $\begin{array}{l}\operatorname{LSD}_{(0.05)} \text { tillage } \\
\text { LSD }_{(0.05)} \text { nitrogen } \\
\text { LSD }_{(0.05)} \text { tillage } \times \text { nitrogen }\end{array}$ & & $\begin{array}{l}\text { NS } \\
\text { NS } \\
\text { NS }\end{array}$ & & \\
\hline & Moldboard plow§ & $\begin{array}{r}0 \\
45\end{array}$ & $\begin{array}{l}2443 \pm 143 \\
2458 \pm 389\end{array}$ & $\begin{array}{l}2433 \\
2433\end{array}$ & $\begin{array}{c}0 \\
-1\end{array}$ \\
\hline & Subsurface tillage & $\mathbf{0}$ & $2194 \pm 154$ & 4043 & 84 \\
\hline & & 45 & $2335 \pm 67$ & 4043 & 73 \\
\hline \multirow{7}{*}{$1980-1981$} & No tillage & 0 & $1831 \pm 172$ & 1571 & -14 \\
\hline & $\begin{array}{l}\operatorname{LSD}_{(0.05)} \text { tillage } \\
\text { LSD }_{(0.05)} \text { nitrogen } \\
\text { LSD }_{(0.05)} \text { tillage } \times \text { nitrogen }\end{array}$ & & $\begin{array}{l}2187 \pm 155 \\
223 \\
158 \\
\text { NS }\end{array}$ & 1571 & -28 \\
\hline & Moldboard plow & $\mathbf{0}$ & $3626 \pm 253$ & 7008 & 93 \\
\hline & Subsurface tillage & 0 & $\begin{array}{l}3534 \pm 44 \\
3214 \pm 430\end{array}$ & $\begin{array}{l}7217 \\
6669\end{array}$ & $\begin{array}{l}104 \\
107\end{array}$ \\
\hline & & 45 & $3761 \pm 271$ & 7530 & 100 \\
\hline & No tillage & 0 & $3342 \pm 210$ & 7951 & 138 \\
\hline & $\begin{array}{l}\operatorname{LSD}_{(0.05)} \text { tillage } \\
\operatorname{LSD}_{(0.05)} \text { nitrogen } \\
\operatorname{LSD}_{(0.05)} \text { tillage } \times \text { nitrogen }\end{array}$ & 45 & $\begin{array}{c}3596 \pm 206 \\
\text { NS } \\
162 \\
280\end{array}$ & 8271 & 130 \\
\hline
\end{tabular}

$\dagger$ Mean \pm standard deviation.

$\ddagger$ Deviation $=[$ (simulated-measured $) /$ measured $] \times 100$.

$\S$ Data used for model calibration.

documentation indicates calibration is necessary, it does not clearly specify steps to use in conducting the calibration. The following calibration procedures (Shaffer, 1988; personal communication) were used in this study.

Three crop coefficients [COEF3 (dry matter production), COEF4 (grain production), and COEF5 (leaf production); Shaffer and Pierce, 1987] were separately and systematically changed to calibrate the model. Simulated results were compared with field observations for LAI, dry matter production, and grain production. Coefficients were changed in the following order: COEF5, COEF3, and COEF4. A coefficient was changed until there was $<5 \%$ difference between measured and simulated values for the specific parameter; the coefficient was then assumed to be properly adjusted and the next coefficient was changed using the same criterion. After each coefficient was adjusted to meet the stated criterion, it was not further modified during that calibration effort. When all coefficients met the $\pm 5 \%$ criterion, the model was considered calibrated. Crop coefficients obtained were $0.007,1.45$, and 2.60 for COEF5, COEF3, and COEF4 coefficients, respectively. These coefficients were used for all treatment-year combinations unless stated otherwise. Although these unitless factors were used to adjust model response to specific conditions, no independent mechanism of evaluating the appropriateness of these fitted values was available.

\section{RESULTS}

\section{Field Wheat Yields}

Precipitation for all $3 \mathrm{y}$ of the study was below normal. The Season 1 crop year (September-July) had the least rainfall $(316 \mathrm{~mm}, 28 \%$ below normal). During the critical spring growth and grain filling periods (April-July), the Season 2 crop had only $168 \mathrm{~mm}$ pre- cipitation (37\% below the normal of $266 \mathrm{~mm}$ for the period) compared to 226 and $276 \mathrm{~mm}$ for the Season 1 and 3 crops, respectively.

Grain yield (Table 2) was affected by tillage operations during Season 2 and by $\mathrm{N}$ levels during Seasons 2 and 3 . The interaction of tillage and $\mathbf{N}$ treatments was significant only during Season 3. Below-normal precipitation resulted in low grain yield during Season 2. That year, moldboard plow, subsurface tillage, and no tillage treatments produced 81,78 , and $71 \%$ of the mean grain produced by the respective treatments during the entire study (1978 through 1981; Table 2).

\section{Simulation: Dry Matter and Grain Yield}

Simulated dry matter production results for all tillage treatments for Season 2 are shown in Fig. 2. Approximately $30 \%$ of the total dry matter was produced before winter. No growth occurred during the dormant period (16 December through $1 \mathrm{March}$ ). Simulated growth after dormancy was nearly linear until about $40 \mathrm{~d}$ before harvest. Generally, simulated total dry matter near the end of grain filling agreed well (within the range of field observations) with measured total dry matter.

Grain yield accumulation for all treatments followed the expected sigmoid curve with grain fill starting in mid-June (Fig. 3). Simulated grain yield agreed well $( \pm 1 \%$ ) with measured grain yields for the moldboard plow during Season 2 (Table 2). Grain yield, however, was overestimated ( 73 to $84 \%$ ) for the subsurface tillage treatment and underestimated (14 to $28 \%$ ) for the no tillage treatment for the same season. 


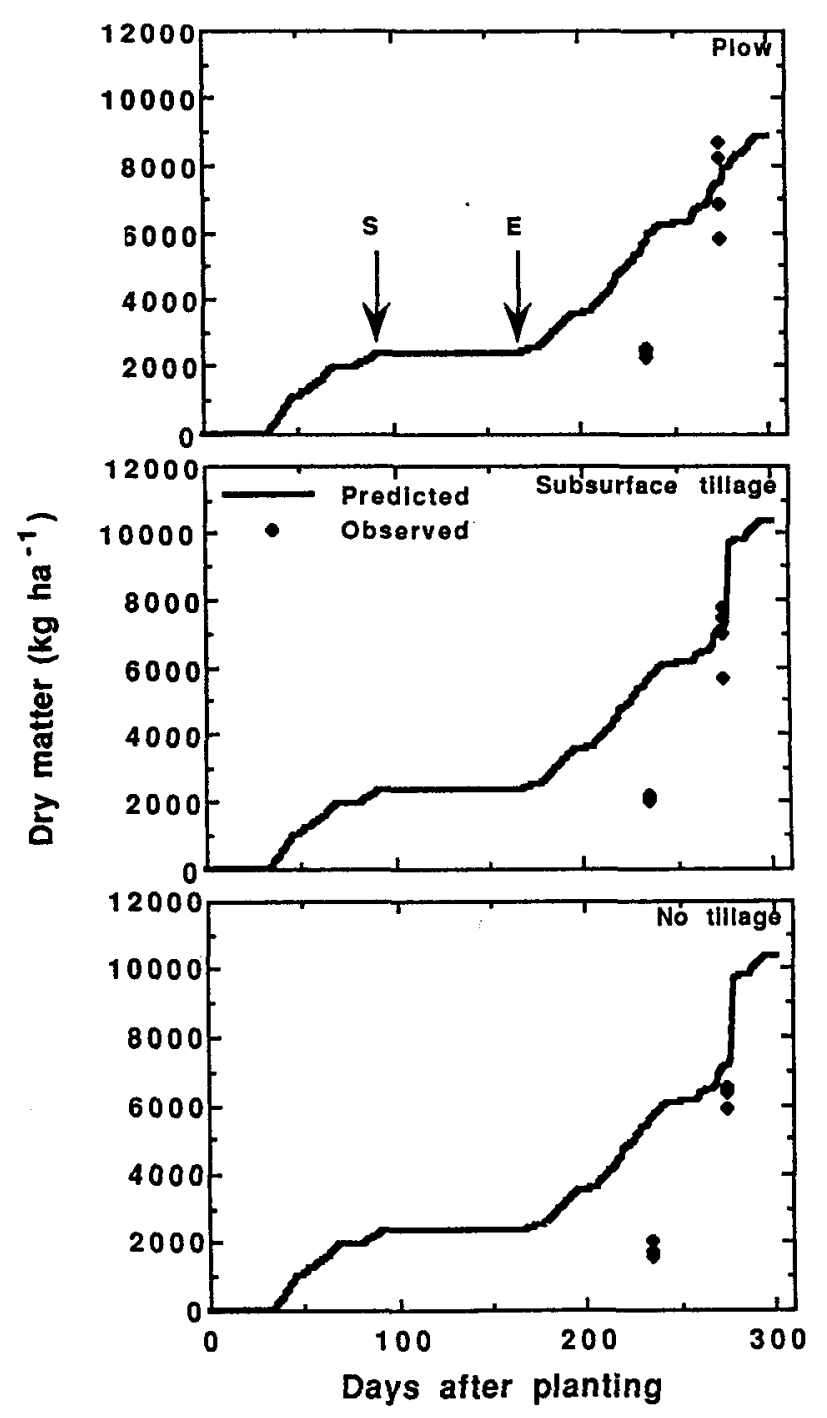

Fig. 2. Measured and simulated total dry matter production for all tillage treatments (no $N$ ) for the 1979-1980 cropping season (Season 2). Arrows indicate the start (S; $95 \mathrm{~d}$ after planting, 16 December) and end (E; $170 \mathrm{~d}$ after planting, 1 March) of dormancy. Sampling occurred at two dates (245 and $275 \mathrm{~d}$ after planting) on four replications.

During Season 2, there were no substantial differences in simulated results between treatments with or without $\mathrm{N}$ fertilizer. For Season 1 , the model overestimated grain yield by $61 \%$ to $99 \%$ for the various treatments. This overestimation may have been a result of low observed grain yields due to poor weed control during Season 1. Overestimations, from 93 to $138 \%$, were observed in the simulated results for Season 3 . The model simulated grain yield differences ranging from 50 to $861 \mathrm{~kg} \mathrm{ha}^{-1}$ due to $\mathrm{N}$ fertilization in the Seasons 1 and 3.

\section{Simulation: Sensitivity Analysis}

Crop Coefficients. In an attempt to evaluate the performance of the model with a different set of calibration coefficients, we calibrated the model to the leaf, dry matter, and grain production from the experimental units producing the maximum and minimum grain yields among the four replications for the

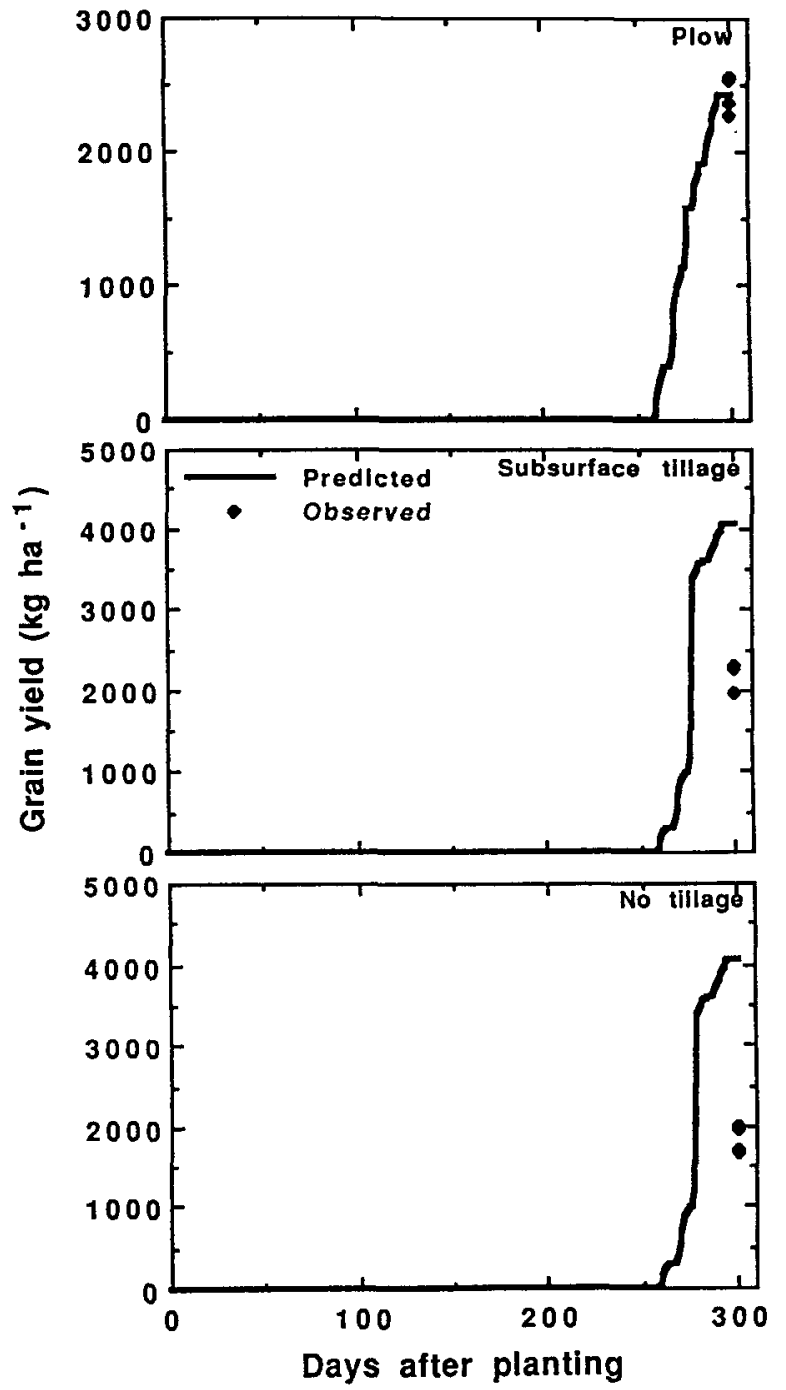

Fig. 3. Measured and simulated grain yield for all tillage treatments for 1979-1980 cropping season (Season 2). Sampling occurred at a single date ( $300 \mathrm{~d}$ after planting) on four replications.

non-fertilized, moldboard plow treatment during Season 2 . In each case, the procedure outlined previously was used to conduct this calibration of the model. Calibration with data from the experimental unit producing the greatest yield (maximum) resulted in coefficients of $0.007,1.15$, and 2.40 for COEF5, COEF3, and COEF4, respectively; calibration with data from the experimental unit with the least grain yield (minimum) resulted in coefficients of $0.007,1.60$, and 2.70 , respectively.

Simulated results were sensitive to the crop coefficients used in calibration (Table 3). Simulations with the coefficients selected by calibration with the minimum values resulted in greater predicted yield for Season 1 (compared to the predictions with the calibration coefficients generated with the observed mean values), however the reverse was true on the Season 3 . Yield predicted for the subsurface tillage treatment during Season 2 using coefficients selected by calibration with the maximum observed values was not realistic. Throughout our testing of the model with 
Table 3. Simulated grain yield of winter wheat grown under three fallow tillage practices. The model was calibrated with minimum, mean, and maximum observed (among replications) yield values from the moldboard plow-no nitrogen treatment during the 1979-80 season. Numbers in parenthesis are minimum and maximum observed grain yield for the respective treatments. Observed mean yields are presented in Table 2.

\begin{tabular}{|c|c|c|c|c|}
\hline \multirow{2}{*}{$\begin{array}{l}\text { Cropping- } \\
\text { season }\end{array}$} & \multirow[b]{2}{*}{ Tillage } & \multicolumn{3}{|c|}{ Simulated grain yield } \\
\hline & & Minimum $\dagger$ & Mean $\ddagger$ & Maximum $\S$ \\
\hline \multirow{3}{*}{ 1978-1979 } & Moldboard plow & $5002(2623)$ & $-\mathrm{kg} \mathrm{ha}^{-}$ & $4905(3215)$ \\
\hline & Subsurface tillage & $4886(2340)$ & $\begin{array}{l}4941 \\
4823\end{array}$ & $4854(3221)$ \\
\hline & No tillage & $5870(2609)$ & 5818 & 5741 (3241) \\
\hline \multirow[t]{3}{*}{$1979-1980$} & Moldboard plow & $2385(2280)$ & 2433 & $2550(2569)$ \\
\hline & Subsurface tillage & $4062(1964)$ & 4043 & $316500(2280) \#$ \\
\hline & No tillage & $1526(1655)$ & 1571 & $1654(2004)$ \\
\hline \multirow[t]{2}{*}{$1980-1981$} & Moldboard plow & $6542(3268)$ & 7008 & $5806(3847)$ \\
\hline & $\begin{array}{l}\text { Subsurface tillage } \\
\text { No tillage }\end{array}$ & $\begin{array}{l}6711(2710) \\
8111(3100)\end{array}$ & $\begin{array}{l}6669 \\
7951\end{array}$ & $\begin{array}{l}6330(3726) \\
7678(3544)\end{array}$ \\
\hline
\end{tabular}

$\dagger$ COEF5 $=0.007$, COEF $3=1.60$, and COEF $4=2.70$.

$\ddagger$ COEF5 $=0.007$, COEF3 $=1.45$, and COEF4 $=2.60$.

$\S$ COEF5 $=0.007$, COEF3 $=1.15$, and COEF $4=2.40$.

T) Data used for model calibration.

\# Not a misprint; simulated yield was $78 \times$ the mean value.

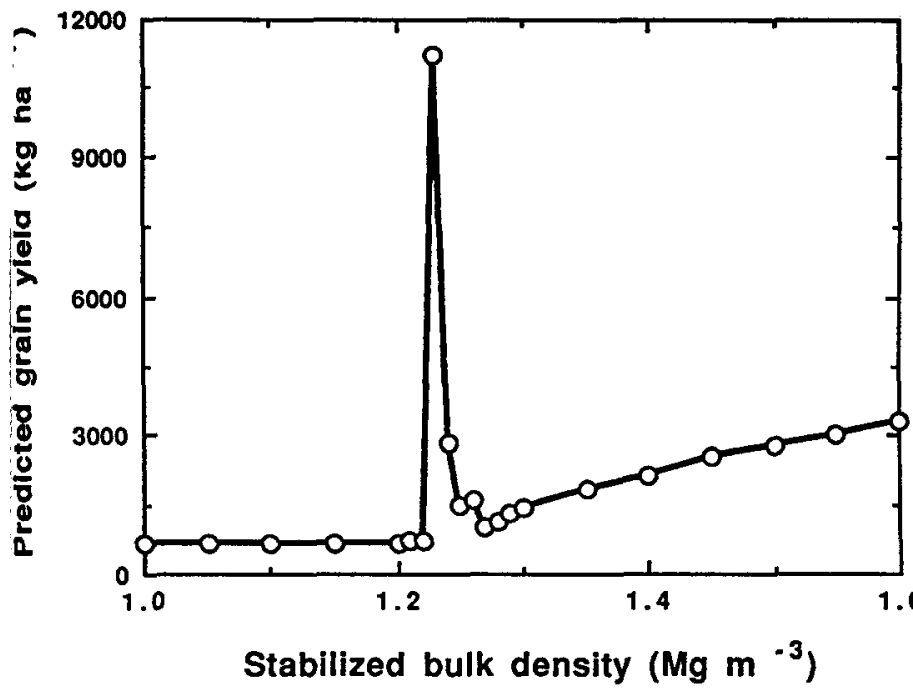

Fig. 4. Nitrogen-Tillage-Residue Management (NTRM) modelpredicted yield response to various "stabilized soil bulk density" (SBD) values. Predictions are for the general conditions of the plow-no nitrogen treatment during 19791980 (Season 2).

various calibration coefficients, predictions one to two orders of magnitude greater than expected occurred occasionally.

Tillage and Soil Bulk Density. Tillage operations are intended to control weeds, loosen the soil, and hence, create a layer of soil that is desirable for seed germination, seedling emergence, and crop development and growth. The physical condition may, in turn, translate into a greater rate of crop development, growth, and yield. Bulk density is one measure of the soil physical condition, but it must be evaluated within the context of soil texture. A silt loam soil with a bulk density greater than $1.6 \mathrm{Mg} \mathrm{m}^{-3}$ would be considered to restrict root penetration (Grossman and Berdanier, 1982). Other soil physical properties (soil strength, porosity, and saturated water content) can be clearly identified as changing with bulk density. Within the simulation, additional properties or processes may be

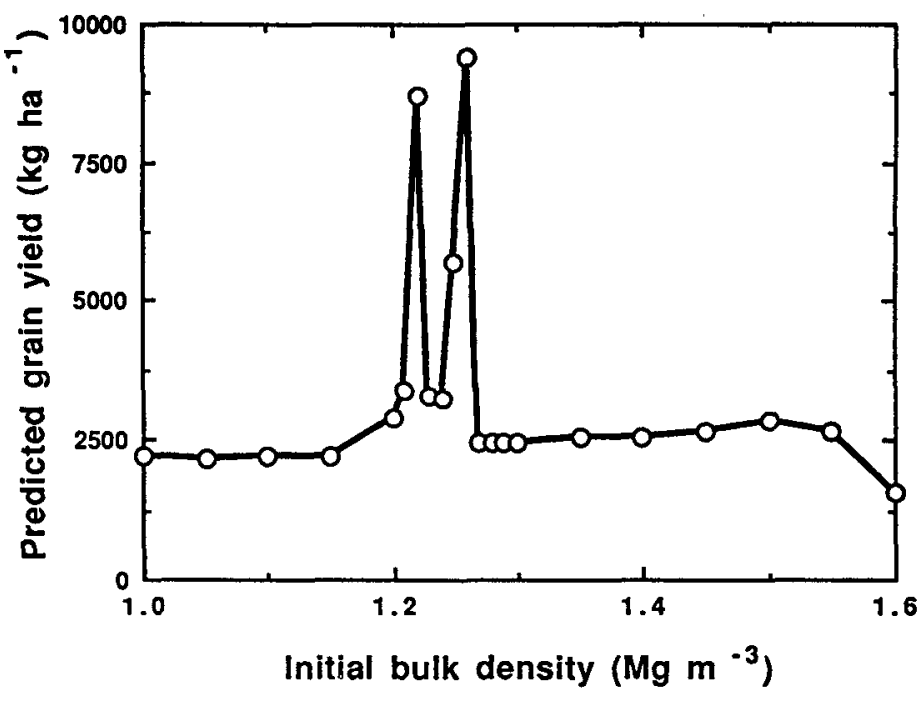

Fig. 5. Nitrogen-Tillage-Residue Management (NTRM) modelpredicted yield response to various initial soil bulk density values and stabilized bulk density of $1.44 \mathrm{Mg} \mathrm{m}^{-3}$.

influenced by bulk density but are not clearly identified.

The NTRM model was developed to simulate the effects of several management practices, including tillage, on crop yield. At the time of tillage, the model reduces the bulk density in the tilled layer depending upon the type of tillage. This layer of soil subsequently reconsolidates over time to approach a predetermined bulk density called "stabilized bulk density" (SBD) in the model. Predicted grain yield was quite sensitive to the input values for SBD (Fig. 4). Stabilized bulk density values near $1.25 \mathrm{Mg} \mathrm{m}^{-3}$ resulted in extreme changes in predicted grain yields. Stabilized bulk density values less than $1.20 \mathrm{Mg} \mathrm{m}^{-3}$ or greater than $1.50 \mathrm{Mg} \mathrm{m}^{-3}$ would be very uncommon in medium-textured soils such as the one used in this study.

Similar to results found for changes in SBD, minor $\left( \pm 0.01 \mathrm{Mg} \mathrm{m}^{-3}\right.$ ) changes in the initial bulk density between 1.20 to $1.30 \mathrm{Mg} \mathrm{m}^{-3}$ resulted in large changes 


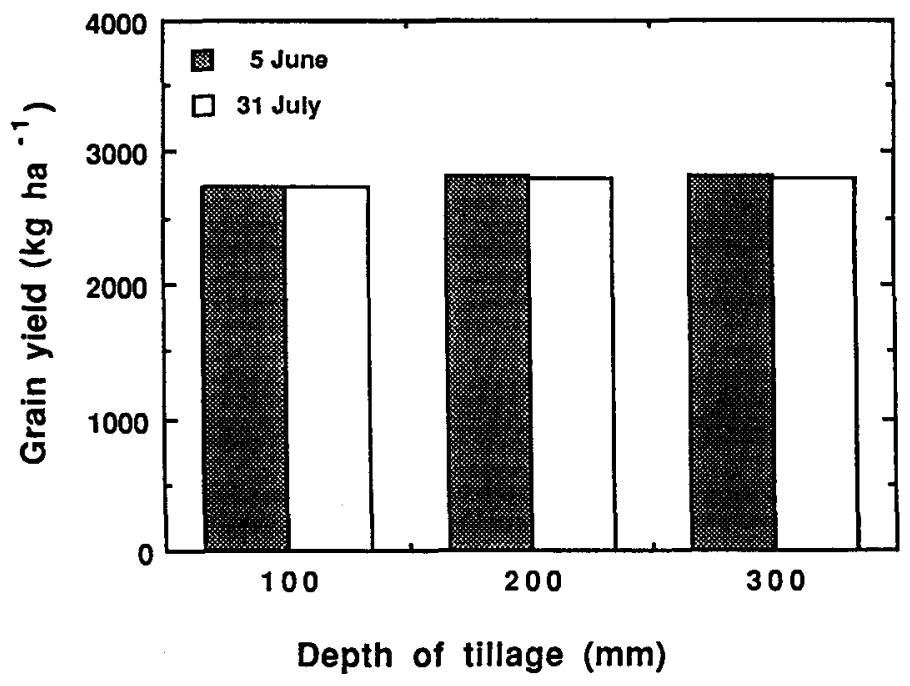

Fig. 6. Nitrogen-Tillage-Residue Management (NTRM) modelpredicted yield response to tillage (plow) to several depths on two dates.

in predicted grain yield (Fig. 5). Changes of this magnitude in bulk density in the field seldom translate to measurable yield differences. We have no explanation for this result, although numerical instability is possible. For all simulations, physical consistency of input files was maintained as bulk density was changed; that is, saturated soil water content (another input variable) was changed in concert with bulk density in the input files.

Tillage Depth and Frequency. To further evaluate the flexibility of NTRM as a tool for evaluating tillage management systems, depth and number of tillage operations were varied within the general conditions of the Season 2 moldboard plow treatment. Simulation of one tillage operation on either 5 June or 31 July in the fallow year to depths up to $300 \mathrm{~mm}$ resulted in essentially no difference in predicted grain yield (Fig. 6 ). As the number of tillage (moldboard plow) operations to a depth of $100 \mathrm{~mm}$ increased from one to four, predicted yields increased, with the amount of increase decreasing as the number of tillage operations increased (Fig. 7).

\section{DISCUSSION}

Although simulation models may provide an economical and convenient method of analyzing crop management practices, results of simulation analyses are largely a function of the characteristics of the model employed in the exercise. Nitrogen Tillage Residue Management appears to be the model of choice to analyze tillage and residue management practices. Several situations however, limit the usefulness of the model. Although documentation (Shaffer and Pierce, 1987; Shaffer and Larson, 1987) indicated the model is applicable for 20 crop species including winter wheat, modifications were necessary to make the model functional for winter wheat. Use of algorithms which limit consideration of soil temperatures $\leq 0^{\circ} \mathrm{C}$ for $\mathrm{N}$ transformations constrains the application of the model in temperate climates.

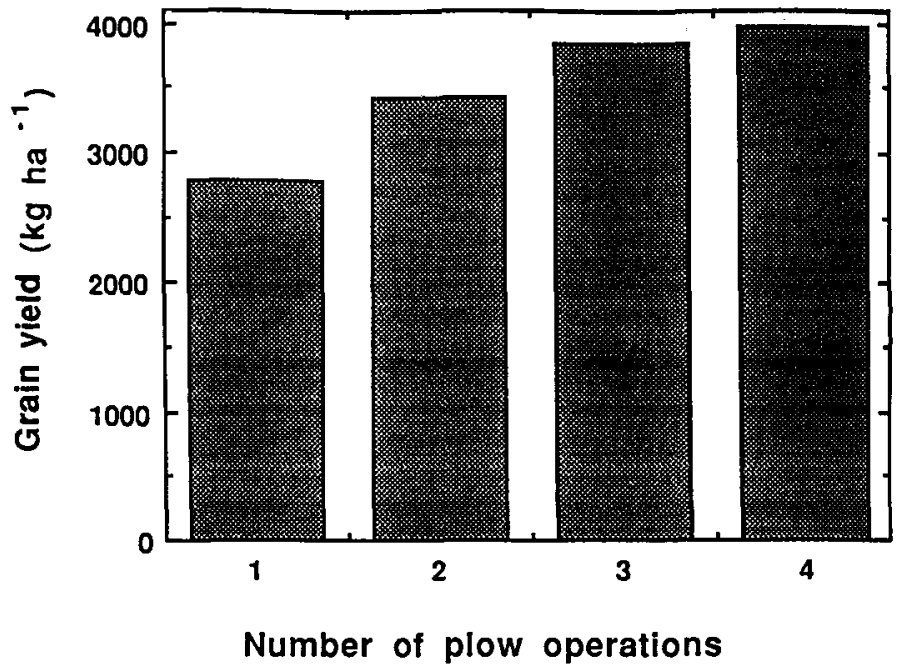

Fig. 7. Nitrogen-Tillage-Residue Management (NTRM) modelpredicted yield response to various number of tillage (plow) operations to $100 \mathrm{~mm}$.

The need to use "dormancy" to limit growth of winter wheat during the winter months suggests the development and growth routines are not sufficiently sensitive at low temperatures to provide realistic predictions of growth of winter wheat. The model needs modification so that low temperatures interact with accumulated thermal time and temperature-sensitive metabolic activity to limit development and growth, without the imposition of dormancy.

Deviations between measured and simulated grain yields may have resulted from several factors. One factor contributing to discrepancies may have been the absence of some meteorological data (pan evaporation and wind speed) from the site. Data from a station 80 $\mathrm{km}$ north of the experimental site were used. There is a possibility that using pan evaporation and wind speed data from a distant site could result in the observed discrepancies. We feel the use of remote data is justified and affected our interpretations to a minor extent because, within a season, the weather data were constant among treatments. In addition, to test the sensitivity of the model to these inputs, we increased and decreased the daily input values for wind speed and pan evaporation 10,20, and $30 \%$. Changing wind speed through this range had no effect on simulated grain yield. A $30 \%$ change in pan evaporation resulted in about a 15\% (opposite sign) change in predicted grain yield. Successful use of NTRM when some of the weather input data came from a remote location has been previously reported (Swan et al., 1987).

The relatively limited predictive ability of NTRM for Season 1 and 3 may be associated with the different rainfall amounts received in the April to July period. The year used for calibration, Season 2 (1979 to 1980), had the least rainfall during this period. This suggests that calibration under relatively stressful conditions may not extrapolate accurately. This, in sequence, suggests algorithms used in NTRM may not be adequate for modeling stressful environments.

Comparison of simulated and observed results within the year of calibration were reasonably accurate. Validity of year-to-year comparison of simulation re- 
sults, however, may depend upon year-to-year variability of crop coefficients as well as meteorological conditions. The model may need to be calibrated for different years, especially if meteorological conditions differ substantially. With limited field data for validation, yearly calibration is impractical and constrains the general usefulness of the model, especially in continental climates that are characterized by large year-to-year variation in weather conditions.

In light of these results with NTRM, we conclude that several improvements are needed if this model is to be used to assess winter wheat management practices. Suggested improvements are: (i) allow simulation with soil temperatures $\leq 0{ }^{\circ} \mathrm{C}$ (this change has been incorporated into the current version of the model); (ii) generate a more realistic algorithm for low temperature to limit crop development and growth; and (iii) reduce sensitivity of NTRM to minor changes in both stabilized and initial soil bulk density. Lastly, a calibration procedure should be documented that results in a unique set of coefficients that can be unambiguously determined for the proposed application. Model documentation should aid the user in understanding the physical or physiological significance of the calibration coefficients and in identifying unrealistic values. To accomplish this, constraints on model parameter values may be required to control erratic and ambiguous responses to crop coefficients. Documented and tested calibration procedures are essential elements in the model's future usefulness. Even with optimum calibration, however, the response of the model to bulk density may limit the model's use to study the effects of compaction or its amelioration in winter wheat production systems. This research high- lights the necessity for care in calibration of NTRM and in validation of results obtained.

\section{ACKNOWLEDGMENTS}

This research was supported in part by Grant no. I-81284 from BARD, The United States-Israel Binational Agricultural Research and Development Fund. The authors wish to acknowledge the help of Dr. M. J. Shaffer for his valuable assistance in several stages of model evaluation and Mr. W. Dailey, Dr. M. Akhter, and Mr. W. Sorensen for providing valuable computer technical support.

\section{REFERENCES}

Broder, M. W., J. W. Doran, G. A. Peterson, and C. R. Fenster. 1984. Fallow tillage influence on spring populations of nitrifiers, denitrifiers, and available nitrogen. Soil Sci. Soc. Am. J. 48:1060-1067.

Fenster, C. R., and G. A. Peterson. 1979. Effect of no-tillage fallow as compared to conventional tillage in a wheat-fallow system. Nebraska Agric. Exp. Stn. Res. Bull. 289.

Grosman, R. B., and C. R. Berdanier. 1982. Erosion tolerance for cropland: Application of the soil survey data base. p. 113130. In B. L. Schmidt, R. R. Allmaras, J. V. Mannering, and R. I. Papendick (ed.) Determinants of soil loss tolerance. ASA Spec. Publ. 45. ASA and SSSA, Madison, Wis.

Mielke, L. N., J. W. Doran, and K. A. Richards. 1986. Physical environment near the surface of plowed and no-tilled soils. Soil Tillage Res. 7:355-366.

Shaffer, M. J., and W. E. Larson. 1987. NTRM, a soil-crop simulation model for nitrogen, tillage, and crop residue management. USDA-ARS Conserv. Res. Rep. 34-1.

Shaffer, M. J., and F. J. Pierce. 1987. A user's guide to the Nitrogen-Tillage-Residue Management (NTRM) simulation model. USDA-ARS Conserv. Res. Rep. 34-2.

Swan, J. B., M. J. Shaffer, W. H. Paulson, and A. E. Peterson. 1987. Simulating the effect of soil depth and climatic factors on corn yield. Soil Sci. Soc. Am. J. 51:1025-1032.

Wilhelm, W. W., L. N. Mielke, and C. R. Fenster. 1982. Root development of winter wheat as related to tillage practice in western Nebraska. Agron. J. 74:85-88. 